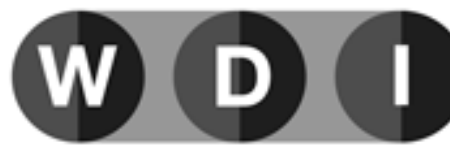

William Davidson Institute

AT THE UNIVERSITY OF MICHIGAN

\title{
Measuring and analyzing the non-monetary approach of multidimensional poverty by the basic needs in Togo
}

By: Yawo Agbényégan NOGLO

William Davidson Institute Working Paper Number 1083

August 2014 


\title{
Measuring and analyzing the non-monetary approach of multidimensional poverty by the basic needs in Togo
}

\author{
Yawo Agbényégan NOGLO \\ Paris-West University Nanterre La Défense (France) \\ Email: noglohonore@hotmail.fr
}

Dr. Yawo Agbényégan NOGLO holds a PHD in Economics at the University of Paris-West Nanterre La Défense (France). His researches focus on poverty and inequality and the effectiveness of targeting policies. As a teaching fellow, he teaches Macroeconomics, Statistics and Econometrics (University of Paris-West Nanterre La Défense) and Microeconomics at the University of East Paris Créteil Val de Marne (France). 


\begin{abstract}
:
This paper aims at measuring and analyzing the non-monetary aspect of multidimensional poverty by the basic needs according to the characteristics of household head. This is the first study in this matter in Togo and using the Multidimensional Correspondence Analysis (MCA) techniques to construct a Composite Poverty Indicator (CPI). Moreover, we use the most recent data from the country survey QUIBB 2006. The results of the incidence of multidimensional poverty by two approaches (MCA and FGT) suggest that the households with larger size, living in rural area, whose head is male, aged between 51 and 99, less educated are the poorest. The findings are the same as those found in the monetary approach at the poverty line, leading to a conclusion that there is a positive correlation between monetary and non-monetary poverty. Finally, we propose some recommendations in terms of socioeconomic policies for alleviating multidimensional poverty.
\end{abstract}

Key words: Multidimensional poverty, Basic needs, Characteristics of household head, Multiple Correspondence Analysis (MCA), Composite Poverty Indicator (CPI), FGT index, Togo

JEL Classifications: I31, I32

\title{
Introduction
}

Togo is one of the least developed countries (LDCs). According to the United Nations Development Programme (UNDP) report 2011, with a gross national income per capita estimated at \$798 (PPP constant 2005) and a Human Development Index (HDI) of 0.435, Togo is ranked $162^{\text {nd }}$ of 183 countries in the world. After the political crisis of the 1990s, which had serious economic consequences, Togo began to record an increase in its real growth rate in 2006 and this reached 3.4 per cent in 2010 (ADF and AfDB report, 2011). This performance is linked to efforts in terms of investment, control of inflation and debt reduction. However, this positive growth is insufficient to have had a serious impact on the multifaceted problems of poverty in the country. Thus, of the eight Millennium Development Goals (MDGs) for 2015, Togo is expected to achieve goals 2 and 6: universal primary education and the fight against HIV/AIDS (International Monetary Fund Report No. 10/33, 2010).

Poverty is deprivation of basic needs: income, food, access to basic social services and so on. With regard to the monetary aspect, the first study on the poverty profile of Togo was made by the World Bank in 1998 based on updated data from the 1989 Consumer Budget surveys. This study revealed that 35.3 per cent of the population lived in poverty in 1998 as against 32.3 per cent in 1989 (UNDP, 2004). This deplorable situation is explained by the negative consequences of the sociopolitical crisis, in particular the suspension of international cooperation with the country from 1993. The most recent report about that dimension of poverty is the one based on the QUIBB 2006 survey. According to that study, 61.7 per cent of the population was poor and the poverty levels were particularly high in the Savannah (90.5 per cent), Central (77.7 per cent) and Kara (75 per cent) regions (Directorate General of Statistics and National Accounts of Togo (DGSCN, 2007)). 
Concerning the non-monetary dimension of poverty, Lawson Body and al. (2007) showed that between 1988 and 1998 the variation in the relative contribution of habitat (7.89 per cent) and communication (1.88 per cent) contributed much to households' well-being. With regard to studies carried out by Djoke and Agbodji (2009) on child poverty in four countries of the West African Economic and Monetary Union (WAEMU), breast-feeding, access to vitamin and micronutrients helped to reduce poverty and disease occurrence (diarrhoea, fever, difficulty breathing). As for Noglo (2014), from QUIBB 2006 data constructed a composite index based on seven housing conditions. After setting five conditions as non-monetary poverty threshold, the author showed that large families did not have a normal life in the house.

Our research is interesting because, no study has been conducted yet in Togo linking several dimensions of poverty (infrastructural and condition of existence) to the characteristics of the head of household whereas studies exist such as that of Ki and al. (2005). Thus the purpose of this article is the measurement and analysis of the non-monetary approach of multidimensional poverty by the characteristics of household head. We precisely try to respond to the following question: what is the link between the characteristics of household head and the household multidimensional poverty? We intend to fill the gap in the literature by addressing that poverty issue and make some recommendations in terms of socioeconomics policies.

The paper is presented as follows: the first section is devoted to the concepts, methods and data. Then in the next section, we discuss our empirical results and finally conclude with recommendations of policies.

\section{Concepts, methods and data}

Two major meanings exist in the literature to define the concept of well-being. The monetary approach that likens the welfare to financial resources such as expenditure or income. Then, the non-monetary aspect that takes into account some attributes, such as access to basic social services (drinking water, sanitation facilities, health services, basic education and transport services).

The monetary dimension translates a narrow conception of well-being (Lachaud, 1998; Deaton, 2003) and does not take into account certain factors that have utility but which are not quantifiable as non-market goods and non-material dimensions of the human condition (Ravallion, 1996). Indeed, the non-monetary attributes above-mentioned and many others that may exist are the dimensions of well-being, thus their inclusion provides relevant information which are not always considered in the one-dimensional monetary approach. Hence, the consideration of the non-monetary dimension provides a broader view of policy implementation. Given that income can not be considered as the only targeting means because it reduces the effectiveness of policies (Ponty, 1998), a multidimensional approach of wellbeing is necessary.

The use of this natural alternative in the purpose to construct a well-being indicator permits to study non-monetary poverty. The above-mentioned non-monetary variables will intervene in the determination of the indicator. This method is inspired from various works in PEP (Poverty and Economic Policy), among others, those of Ki and al. (2005), Booysen and al. (2007), Lawson Body and al. (2007)... 


\section{I.1 Composite Poverty Indicator (CPI)}

The basic non-monetary welfare main dimensions used for the CPI are basic infrastructure, energy, housing and sanitation. Several methods allow to construct a CPI and they mainly include the entropy approach, the logic of fuzzy sets and the method of inertia.

The entropy and inertia approaches originate from the field of dynamic mechanics and static mechanics respectively. The entropy method has been the keystone of Massoumi (1986), who, using a measure of divergence between two distributions, has designed an optimal composite indicator. This minimizes a weighted sum of pairwise divergences.

Cerioli and Zani (1990) for measuring multidimensional poverty developed multivariate method based on the theory of fuzzy sets. This method allows a construction of indices comprising the different dimensions of poverty. Then, Dagnum and Costa (2004), introduced a one-dimensional aspect through one-dimensional indices. This synthetic decomposition consists in measuring the state of deprivation of each attribute and evaluating their contributions to the overall level of poverty. Thus, the poverty of a person is identified by its membership degree in fuzzy sets and this, to each of the attributes of poverty respectively. The state of poverty by groups (region, level of education, religion, household size...) can also be studied by dividing the economic surface into $k$ groups $\left(S_{k}\right)$ of size $n_{k}(k=1, \ldots, s)$ (Mussard and Pi Alperin, 2005). The criticism that can be formulated against these two methods is the arbitrariness behind the choice of weights for each attribute.

The best solutions to this problem are provided by the approach of inertia. This latter is based on factor analysis techniques developed by Meulman (1992), Bry (1996), Volle (1993) and Escofier and Pagès (1990). These tools include the Multiple Correspondence Analysis (MCA) allowing to determine a CPI with the least possible arbitrary. The MCA technique suggested by Asselin (2002) is better suited for data that include a set of primary variables representing different categories that can take primary dimensions reflecting the living conditions of households. Thus, it allows to account accurately for the aspects of living conditions considered relevant. Measuring non-monetary poverty will be based on the indicator generated by the MCA. According to Asselin (2002), the technique leading to the construction of the CPI is as follows: Let us consider $\mathrm{K}$ primary indicators representing the living conditions of household such as the type of ground or floor in housing for example. The basic idea is to summarize the information provided by these qualitative indicators into a single composite index that we call $C_{i}$. The composite indicator is written in the general form as follows:

$$
C_{i}=\sum_{j=1}^{K} \gamma_{i} I_{i j}
$$

with $I_{i j}$ the primary indicator $j(1 \ldots \ldots \mathrm{K})$ for a household $i(i=1 \ldots \ldots \mathrm{n}) . \gamma_{i}$ is the weight assigned to the indicator $j$ in the calculation of the composite index $C_{i}$ of household $\boldsymbol{i}$

Thus, the CPI can be written again in the following functional form: 


$$
C_{i}=\frac{\sum_{k=1}^{K} \sum_{j_{k=1}}^{J_{k}} W_{j_{k}}^{k} I_{j_{k}}^{K}}{K},
$$

With $i$ the indice of a household and $C_{i}$ its value for the CPI, $\mathrm{K}$ the number of categorical

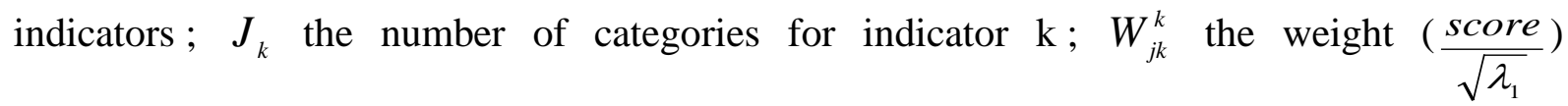
(normalized first axis score) of category $J_{k} ; \lambda_{1}$ the first eigenvalue and $I_{j k}^{K}$ the binary variable $0 / 1$ taking the value 1 when the unit of household has the category $J_{k}$. The weights provided by the MCA correspond to the normalized first axis scores on the first factorial axis. The mean of normalized scores of categorical variables represents the value of the CPI for any household $m$.

Although the method of inertia is an excellent method for constructing a CPI by eliminating the maximum arbitrary, it nevertheless has weaknesses. Indeed, this method only takes into account property and monetary resources in the calculation of the CPI, however, according to Sen (1999), people have the freedom to choose the lifestyle they have good reason to enjoy. In addition, the MCA neither allows to simultaneously analyze multiple tables nor makes concomitant description of links within and between tables. Thus, in terms of inertia, this method could give little weights to certain relevant variables for the analysis of well-being. Finally, the MCA approach does not consider the possible interactions between the variables.

\subsection{The Ascending Hierarchical Classification (AHC)}

The Ascending Hierarchical Classification (AHC) also called the cluster analysis technique is a method of classification of households by the level of well-being. Its objective is to create disjoint classes of households as homogeneous as possible. In other words, among all possible partitions, the one chosen is which provides the maximum between class variance (or the minimum within-class variance).

The characterization of classes implies knowing the meaning of percentages of classes in the modality (CLA / MOD) and the percentage of modality within the class (MOD / CLA). The first indicates the number of individuals with the modality in the class divided by the total number of individuals with the modality. In other words, it is the percentage of people who have the modality and belonging to the class. For example CLA / MOD $=100 \%$ means that if a person has the modality then it belongs to the class. Note that the CLA / MOD reflects the incidence of multidimensional poverty by the AHC method. As for MOD / CLA, it is the number of individuals with the modality in the class divided by the total number of people of the class. For example MOD / CLA $=100 \%$ means that all individuals in the class have the modality.

\section{I.3 Poverty index}

The CPI per household obtained from the final MCA can be positive, indicating nonmonetary wealth or negative reflecting poverty. To address these issues of negative values in the calculation of poverty level, the composite indices are translated by adding to each original CPI of household $i$, the absolute value of the minimum value of the set of indicators. 
Following Duclos and Araar (2006), the translated CPI $\left(C P I_{i}^{*}\right)$ which is positive for each household $i$ is expressed as follows:

$$
C P I_{i}^{*}=C P I_{i}-\min \left(C P I_{i}\right) \text {, }
$$

Where $-\min \left(C P I_{i}\right)=1,05$ is the absolute value of the smallest value from the original CPI. The $C P I^{*}$ generated will all be positive by construction but the level of welfare of households remains ordered similarly between the first and the translated CPI.

Note that, the translation of the CPI will affect the mean of the distribution and thus the results of poverty measures (Sahn and Stifel, 2003). Indeed, except the incidence of poverty, this transformation will influence the poverty gap and the severity of poverty

Several poverty indices exist in the literature. However, for this study, we apply for the nonmonetary dimension of poverty the FGT class of decomposable indices developed by Foster, Greer and Thorbecke (1984), because they are popular for their decomposition properties of poverty into subgroups. The general formula of these indices is the following:

$$
P_{\alpha}=\frac{1}{N} \sum_{i=1}^{q}\left(\frac{z-C P I_{i}^{*}}{Z}\right)^{\alpha}
$$

$\mathrm{N}$ is the number of households in the population, $\mathrm{z}$ is the multidimensional poverty line, $C P I_{i}^{*}$ is the translated CPI, $q$ the number of poor, $\alpha \geq 0$ is the poverty aversion parameter. If $\alpha=0$, the index $P_{0}$ (also called the headcount ratio) assesses the incidence of multidimensional poverty that is, the share of households living below the multidimensional poverty threshold.

\section{I.4. Data}

The data are from the most recent survey (QUIBB 2006) on the issue of poverty in Togo. The collation QUIBB was carried out by the General Directorate of Statistics and National Accounts (DGSCN) in cooperation with the World Bank, the UNDP, the United Nations Population Fund (UNFP) and the United Nations Children's Fund (UNICEF). These international institutions funded the survey, which took place from July 4 to August 11, 2006. It is an areolar survey stratified into two stages. At the first stage, 300 Zone of Counting (ZC) were drawn with proportionate probabilities to the size of ZC. The second stage has allowed to have 7500 households from the ZC (25 households per ZC) with respectively 2600 and 4900 in urban and rural areas.

\section{The results}

\section{II.1 Correspondence analysis of multiple dimensions of non-monetary welfare: Final MCA on the CPI variables}

First, a first MCA was carried out and it aims to visualize the various aspects of nonmonetary welfare. It was done on the basis of 18 variables representing the non-monetary dimensions of well-being. Then comes a second MCA whose purpose is to select the relevant 
variables for the construction of the CPI. The main criterion considered is the first axis ordering consistency (FAOC). This principle is a necessary condition for the CPI to order households according to their welfare situation. This means that the coordinates (scores) of modalities of a primary indicator on the first axis must respect the ordinal structure of the well-being indicator.

After applying this procedure, the final MCA takes into account 15 variables with all FAOC property and 31 modalities. The variables definitely selected and their modalities are presented in Table 1.

Table 1- Final list of 15 variables and 31 modalities for the calculation of the Composite Poverty Indicator

\begin{tabular}{|c|c|}
\hline Variables & Modalities \\
\hline \multicolumn{2}{|l|}{ Education } \\
\hline Access to primary school & Less than 30mn/Over 30mn \\
\hline Access to secondary school & Less than 30mn/Over 30mn \\
\hline \multicolumn{2}{|l|}{ Health } \\
\hline Access to a health center & Less than 30mn /Over 30mn \\
\hline \multicolumn{2}{|l|}{ Water source } \\
\hline Access to a water source & Less than 30mn /Over 30mn \\
\hline \multicolumn{2}{|l|}{ Nutrition } \\
\hline Access to food market & Less than 30mn / Over 30mn \\
\hline Often food problems & Yes/No \\
\hline \multicolumn{2}{|l|}{ Public transports } \\
\hline Access to public transport & Less than 30mn /Over 30mn \\
\hline \multicolumn{2}{|l|}{ Housing and sanitation } \\
\hline Roof materials & Durable /Non-durable \\
\hline Wall materials & Durable / Non-durable \\
\hline Floor materials & Durable /Non-durable \\
\hline Disposal of household garbage & $\begin{array}{l}\text { Collection service / In the nature, } \\
\text { Burial, Incineration, Landfill }\end{array}$ \\
\hline Disposal of wastewater & $\begin{array}{l}\text { Wastewater disposal system / In the } \\
\text { nature, On the road. }\end{array}$ \\
\hline \multicolumn{2}{|l|}{ Energy } \\
\hline Mode of lighting & Modern / Non-modern /Others \\
\hline Electricity in the house & Yes / No \\
\hline Combustible for cooking & Modern / Non-modern \\
\hline
\end{tabular}


This table excludes three variables with non-FAOC property such as access to toilet, the supply of drinking water, the housing occupancy status ${ }^{1}$.

The fact of reducing variables has increased the explanatory power of the first factorial axis which has increased from $26,47 \%$ to $31,66 \%$ and that of second axis from $9,01 \%$ to $12,13 \%$ (see the histograms of eigenvalues in annex 1). The first axis with higher explanatory power is the basis to explain the non-monetary welfare and for this reason, it is also named the poverty-wealth axis (or well-being axis). This latter makes a clear separation between rich and poor. The observation of Figure 1 illustrating the results of the final MCA shows that on the first axis the modalities with a positive score increases the well-being while, those with a negative score decreases it. The MCA is the basis for constructing the CPI which will be used in the rest of the study.

Overall, figure 1 highlights two forms of non-monetary poverty and wealth. First, there is the infrastructural poverty which appears through poor access (over $30 \mathrm{~min}$ ) to basic infrastructures (education, health, water source, food market). This type of poverty is beyond the capabilities of households. It is rather closely related to the ability of the government to provide the country with basic infrastructures in view of improving the living conditions of populations.

Then, the vulnerability of human existence. This is the most noticeable because it is related to housing characteristics: non-resistant walls (bamboo, wood, cardboard, sheet metal and clay brick), non-resistant roof (mud brick, clay, straw, tree branches), non-resistant floor (clay and sand). This vulnerability can also be seen by food insecurity, the lack of electricity in the house, the use of archaic means (kerosene lamp, gas lamp, hurricane lamp, candle, firewood) for lighting, the use of non-modern combustible (firewood, charcoal, plant residues) in the kitchen, the disposal of household garbage in the nature and the discharge of wastewater on the road and in the nature given the lack of wastewater disposal system (sewers, sumps...).

As for what is linked to wealth, both dimensions are the opposite aspects of poverty discussed. Indeed, households have easy access to basic infrastructures and are not victim of the vulnerability of human existence.

\footnotetext{
${ }^{1}$ See in brackets the modalities of these three variables: access to toilet (modern toilet, non-modern toilet, no access to toilet), the supply of drinking water (water tanker truck, untreated water, yard tap, water tap in the home, other water sources), the housing occupancy status (family home, homeowner, tenant of dwelling).
} 
Figure 1- First plan of the final MCA

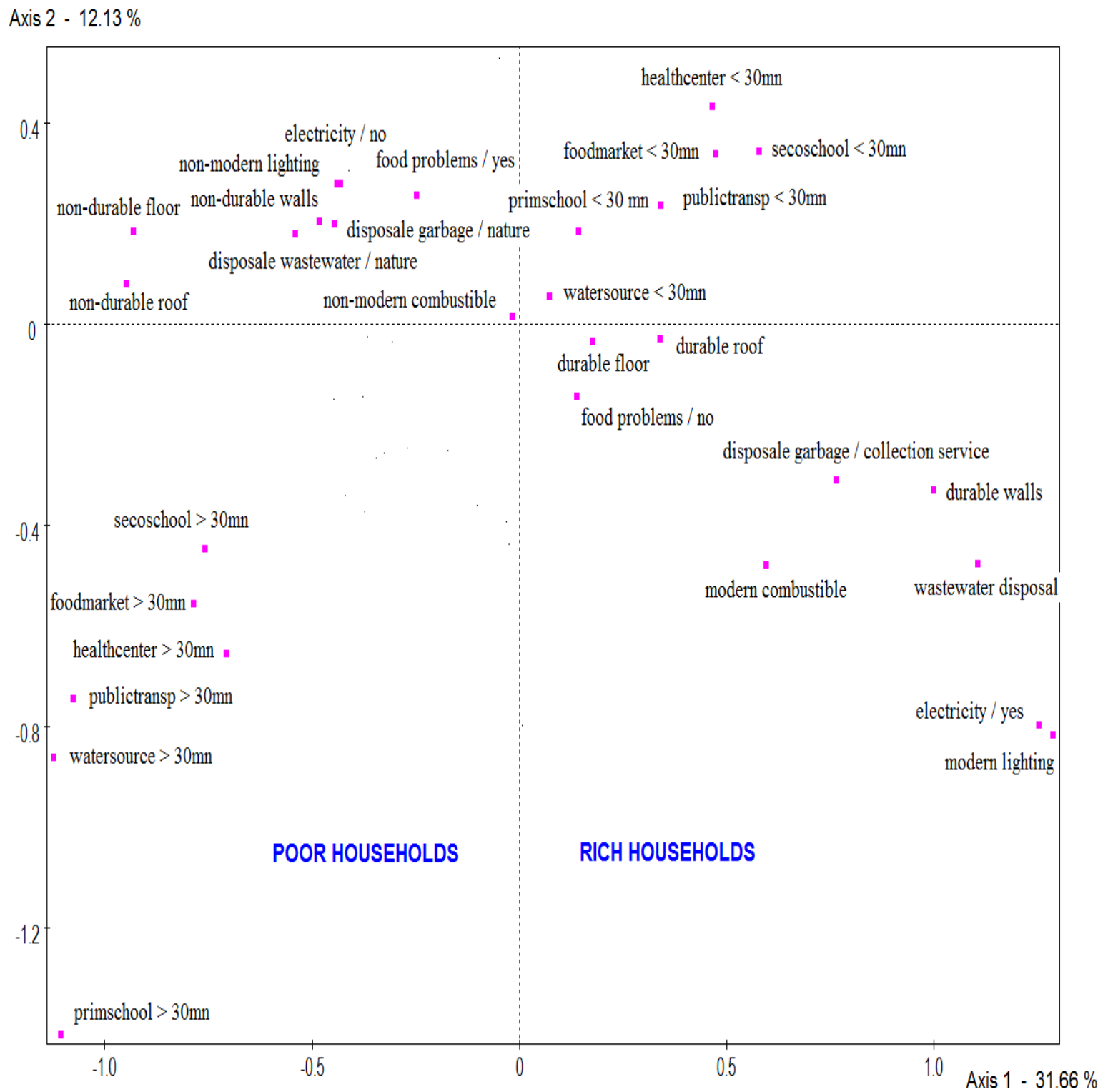

Source: Author’s calculation using QUIBB 2006.

\section{Legend:}

primschool : time taken to reach the nearest primary school; secoschool : time taken to reach the nearest secondary school ; health center : time taken to reach the nearest health center; water source : time taken to reach the nearest water source ; food market : time taken to reach the nearest food market ; public transp : time taken to reach the nearest public transport.

Table 2 below provides the standardized scores of CPI. Let's recall that the weights are standardized scores on the first factorial axis. The most positive scores correspond to modalities such as: the disposal wastewater, the modern lighting mode, the possession of the electricity in the house, the durable wall materials, the collection service for household garbage, and access to secondary school. The most negative scores are linked to low access to infrastructure (primary and secondary school, health center, water source, food markets and 
public transports), non-durable roof and floor materials of housing. As one can see the weights provided by the MCA give to this latter an interesting property: separate at best, poor and rich. Thus the logic of this approach is clear: a modality has a much greater weight when it is increasingly rare. Thus the MCA gives significant weights to scarce and luxurious goods and services that increase the well -being, and high weights to goods and services which are more accessible in reducing welfare. This logic gears a better identification of the poor. Indeed, a household will be all the more poor because it does not have access to basic goods which are accessible to the majority of the population. On the flip side, the household which has access to several luxury goods will tend to have a high standard of living. These situations reflect the reality.

Table 2 also gives the contributions of variables for the construction of the first axis. They describe the share of each variable in the total inertia of the axis. The most contributory variables are firstly: mode of lighting, electricity in housing, wall materials, disposal of wastewater, access to secondary school. Then come secondly: access to food market, public transport, disposal of household garbage and the wall materials. The less contributory modalities are: access to primary school and water source, combustible used for cooking, the floor materials and the food problems.

The cosine-square indicate the quality of the representation of modalities on the first axis: the more the cosine-squared is great, the more the modality is correlated with the axis and therefore well represented on this axis. Thus, the modalities which are best represented on the first factorial axis are those whose variables have the greater contribution. Thus the strong contribution of these variables translates the quality of the linkage between their modalities and the well-being axis.

Finally, the distance to the center is simply the square of the distance of $\chi 2$ from the origin.

Table 2- Scores, contributions and cosine-squared of the final MCA of Togo

\begin{tabular}{|l|c|c|c|c|c|}
\hline \multicolumn{1}{|c|}{ Variables/Modalities } & $\begin{array}{c}\text { Scores on } \\
\text { the first axis }\end{array}$ & Contributions & $\begin{array}{c}\text { Cosine } \\
\text { squared }\end{array}$ & $\begin{array}{c}\text { Distance to } \\
\text { the center }\end{array}$ & Frequencies \\
\hline Access to primary school & 0,14 & 0,4 & 0,16 & 0,13 & 5,90 \\
Less than $30 \mathrm{mn}$ & $-1,11$ & 3,0 & 0,16 & 7,68 & 0,77 \\
Over $30 \mathrm{mn}$ & 0,58 & $\mathbf{3 , 4}$ & & & \\
\hline Access to secondary school & $-0,76$ & 5,2 & 0,44 & 1,31 & 2,78 \\
Less than $30 \mathrm{mn}$ & & $\mathbf{6 , 9}$ & & & \\
Over $30 \mathrm{mn}$ & 0,46 & 2,7 & 0,33 & 0,66 & 4,02 \\
\hline Access to a health center & $-0,71$ & 4,2 & 0,33 & 1,52 & 2,65 \\
Less than 30 mn & & $\mathbf{1 , 7}$ & & & \\
Over $30 \mathrm{mn}$ & 0,07 & 0,1 & 0,08 & 0,06 & 6,27 \\
\hline Access to a water source & & & & \\
Less than 30 mn & &
\end{tabular}




\begin{tabular}{|c|c|c|c|c|c|}
\hline Over $30 \mathrm{mn}$ & $-1,13$ & 1,6 & 0,08 & 15,67 & 0,40 \\
\hline Access to food market & & 7,8 & & & \\
\hline Less than $30 \mathrm{mn}$ & 0,48 & 3,0 & 0,37 & 0,61 & 4,15 \\
\hline Over $30 \mathrm{mn}$ & $-0,78$ & 4,9 & 0,37 & 1,65 & 2,51 \\
\hline Access to public transports & & 7,7 & & & \\
\hline Less than $30 \mathrm{mn}$ & 0,34 & 1,8 & 0,36 & 0,32 & 5,06 \\
\hline Over $30 \mathrm{mn}$ & $-1,07$ & 5,8 & 0,36 & 3,16 & 1,60 \\
\hline Combustible for cooking & & 0,2 & & & \\
\hline Modern & 0,54 & 0,2 & 0,01 & 31,19 & 0,207 \\
\hline Non -modern & $-0,02$ & 0,0 & 0,01 & 0,03 & 6,46 \\
\hline $\begin{array}{l}\text { Disposal of household } \\
\text { garbage }\end{array}$ & & 7,6 & & & \\
\hline In the nature & $-0,48$ & 3,0 & 0,36 & 0,64 & 4,06 \\
\hline Collection service & 0,75 & 4,7 & 0,36 & 1,56 & 2,60 \\
\hline Floor materials & & 3,4 & & & \\
\hline Durable & 0,18 & 0,6 & 0,16 & 0,19 & 5,59 \\
\hline Non -durable & $-0,92$ & 2,9 & 0,16 & 5,22 & 1,07 \\
\hline Wall materials & & 11,3 & & & \\
\hline Durable & 1,00 & 7,4 & 0,54 & 1,84 & 2,34 \\
\hline Non -durable & $-0,54$ & 4,0 & 0,54 & 0,54 & 4,32 \\
\hline Roof materials & & 6,7 & & & \\
\hline Durable & 0,34 & 1,8 & 0,32 & 0,36 & 4,91 \\
\hline Non -durable & $-0,95$ & 5,0 & 0,32 & 2,80 & 1,75 \\
\hline Electricity & & 11,6 & & & \\
\hline Yes & 1,25 & 8,6 & 0,55 & 0,35 & 4,93 \\
\hline No & $-0,44$ & 3,0 & 0,55 & 2,85 & 1,73 \\
\hline Often food problems & & 0,7 & & & \\
\hline Yes & $-0,25$ & 0,5 & 0,03 & 0,56 & 4,26 \\
\hline No & 0,14 & 0,3 & 0,03 & 1,77 & 2,41 \\
\hline Mode of lighting & & 11,6 & & & \\
\hline Modern & 1,27 & 8,6 & 0,55 & 2,95 & 1,69 \\
\hline Non -modern & $-0,43$ & 2,9 & 0,55 & 0,34 & 4,98 \\
\hline Disposal of wastewater & & 10,1 & & & \\
\hline Nature, Road & $-0,44$ & 2,9 & 0,48 & 0,41 & 4,74 \\
\hline Wastewater disposal system & 1,09 & 7,2 & 0,48 & 2,46 & 1,92 \\
\hline
\end{tabular}

Source: Author’s calculation from QUIBB 2006

Note that economists have not yet reached a consensus on the dimensions of well-being that matter, because they rarely justify their choices (Alkire (2006). Thus the attributes selected for our study are those revealed by QUIBB 2006. We would like to include the dimension related 
to the possession of property (motorcycle, car, TV, telephone, fridge...), but these assets do not exist in the database. Finally, as above-mentioned, the translation made in order to have positive CPI influences the mean of the distribution and make the poverty measurements depending on the transformation, and consequently determines the outcome of poverty levels. However, the important thing is not the elaboration of a perfect indicator of well-being but a measure to provide decision makers with results on which will be based policies for alleviating non-monetary poverty.

\section{II.2 Incidence of multidimensional poverty}

\section{II.2.1 Cluster analysis techniques: characteristics of classes}

By performing cluster analysis techniques, we distinguish 2 classes of households: the rich class and the poor class whose weights are $34,53 \%$ and $65,47 \%$ respectively

Nationally, Table 3 characterizing the rich class indicates that among the overrepresented modalities ${ }^{2}$, rich households have satisfactory access to basic needs. Indeed, wealthy families have no energy problems (use of modern lighting and electricity in the house), have a comfortable home (durable walls, roof and floor) and live in a sanitized environment (wastewater disposal system, collection service for household garbage). For example, if in the sample households using modern lighting and electricity are 25,04\% and 25,96\% respectively, in the rich class the percentages are $70.54 \%$ and $71,85 \%$. This class also includes the majority of families which have easy access to basic infrastructures (access to primary and secondary school, public transport, food market, health center, and a source of drinking water) and rarely food problems.

This households live in majority $(87,34 \%)$ in urban area, they are headed by a woman and are small size. These families are in large proportion managed by a head aged between 31 and 50 . The educational levels of these household heads are complete primary and secondary schools; and professional school.

\footnotetext{
${ }^{2}$ A modality is overrepresented if it appears in the class with a percentage significantly superior to the average rate it represents in the sample. Hence, the Test-Value is positive and superior to 2 at usual significant level of $5 \%$.
} 
Table 3 Characteristics of the rich class

Number of households : 2590 - Percentage : 34,53\%

\begin{tabular}{|c|c|c|c|c|c|}
\hline Variables & Modalities & $\begin{array}{c}\text { Test- } \\
\text { Values }\end{array}$ & $\begin{array}{l}\text { \% of class in } \\
\text { the modality } \\
\text { (CLA/MOD) }\end{array}$ & $\begin{array}{l}\text { \% of the } \\
\text { modality in } \\
\text { the class } \\
\text { (MOD/CLA) }\end{array}$ & $\begin{array}{l}\text { Overall } \\
\text { frequency in } \\
\text { the modality }\end{array}$ \\
\hline \multicolumn{6}{|l|}{ Active variables } \\
\hline Mode of lighting & Modern & 68,76 & 97,28 & 70,54 & 25,04 \\
\hline Electricity in the house & Yes & 68,11 & 95,58 & 71,85 & 25,96 \\
\hline Wall materials & Durable & 65,39 & 82,06 & 83,36 & 35,08 \\
\hline Disposal of wastewater & Disposal System & 62,44 & 88,36 & 72,12 & 28,19 \\
\hline Disposal of household garbage & Collection service & 50,78 & 69,29 & 77,26 & 38,51 \\
\hline Roof materials & Durable & 42,33 & 46,50 & 99,15 & 73,64 \\
\hline Access to secondary school & Less than $30 \mathrm{mn}$ & 40,40 & 53,11 & 86,95 & 56,53 \\
\hline Access to public transport & Less than $30 \mathrm{mn}$ & 34,22 & 44,08 & 96,60 & 75,68 \\
\hline Access to food market & Less than $30 \mathrm{mn}$ & 33,81 & 48,35 & 87,03 & 62,16 \\
\hline Floor materials & Durable & 28,15 & 40,47 & 98,26 & 83,84 \\
\hline Access to a health center & Less than $30 \mathrm{mn}$ & 27,31 & 46,41 & 80,77 & 60,11 \\
\hline Access to a water source & Less than $30 \mathrm{mn}$ & 16,09 & 36,52 & 99,31 & 93,89 \\
\hline Access to primary school & Less than $30 \mathrm{mn}$ & 15,63 & 37,42 & 95,87 & 88,48 \\
\hline Often food problems & No & 12,35 & 39,58 & 73,24 & 63,91 \\
\hline Combustible used for cooking & Modern & 5,46 & 52,51 & 4,44 & 2,92 \\
\hline \multicolumn{6}{|l|}{ Illustrative variables } \\
\hline Area of residence & Urban area & 72,43 & 87 & 87,34 & 34,67 \\
\hline Educational level of household head & Comp. Prim. Scho. & 3,86 & 40,71 & 12,86 & 10,91 \\
\hline Educational level of household head & Incomp. Sec. Scho. & 24,56 & 58,40 & 42,12 & 24,91 \\
\hline Educational level of household head & Comp. Sec. Scho. & 11,86 & 71,67 & 6,64 & 3,20 \\
\hline Educational level of household head & Profession. Scho. & 23,09 & 91,98 & 12,39 & 4,65 \\
\hline Size of household & 1-2 people & 12,34 & 49,47 & 25,33 & 17,68 \\
\hline Size of household & 3-4 people & 2,03 & 36,23 & 32,20 & 30,69 \\
\hline Sex of household head & Female & 8,06 & 43,29 & 26,14 & 20,85 \\
\hline Age of household head & 15 - 30 years & 4,65 & 40,75 & 17,53 & 14,85 \\
\hline Age of household head & 31 - 50 years & 5,72 & 37,43 & 58,69 & 54,15 \\
\hline
\end{tabular}

Source: Author’s calculation from QUIBB 2006

Table 4 characterizes the Togolese poor class. We note that the most overrepresented modalities are: energy (lack of electricity in the home and non-modern lighting), the lack of comfort in the house (non-durable walls, roof and floor), sanitation (garbage disposal in the nature, wastewater disposal on the road and in the nature), difficult access to basic infrastructures (secondary school, food market and health center). If, for example in the sample, households with no electricity in the house and no modern lighting source are 73,93 $\%$ and $74,49 \%$ respectively, in the poor class, these rates reach for each of the respective modalities the level of 98,13\% and 98,39\%.

In this poor class, households live mostly in rural areas (93,12\%) and are typical of large size families (5-6 people and 7 people or more). The household heads are men in large proportion, they are in the between 51 and 99 age group. Also, the chiefs of households are not educated or they have incomplete primary school level. 
Table 4- Characteristics of the poor class

Number of households : 4910 - Percentage : 65,47\%

\begin{tabular}{|c|c|c|c|c|c|}
\hline Variables & Modalities & $\begin{array}{l}\text { Test- } \\
\text { Values }\end{array}$ & $\begin{array}{l}\text { \% of class in } \\
\text { the modality } \\
\text { (CLA/MOD) }\end{array}$ & $\begin{array}{c}\% \text { of the } \\
\text { modality in } \\
\text { the class } \\
\text { (MOD/CLA) }\end{array}$ & $\begin{array}{l}\text { Overall } \\
\text { frequency of } \\
\text { the modality }\end{array}$ \\
\hline \multicolumn{6}{|l|}{ Active variables } \\
\hline Electricity in the house & No & 67,91 & 86,89 & 98,13 & 73,93 \\
\hline Mode of lighting & Non -modern & 67,64 & 86,47 & 98,39 & 74,49 \\
\hline Wall materials & Non-durable & 65,31 & 91,19 & 90,24 & 64,79 \\
\hline Disposal of wastewater & Road, nature & 61,69 & 87,10 & 93,67 & 70,40 \\
\hline Disposal of household garbage & On the road & 50,11 & 87,43 & 80,59 & 60,35 \\
\hline Roof materials & Non-durable & 42,44 & 98,98 & 39,71 & 26,27 \\
\hline Access to secondary school & Over 30 mn & 40,27 & 89,74 & 58,98 & 43,03 \\
\hline Access to public transport & Over $30 \mathrm{mn}$ & 34,22 & 95,47 & 34,77 & 23,84 \\
\hline Access to food market & Over $30 \mathrm{mn}$ & 33,72 & 88,24 & 50,57 & 37,52 \\
\hline Floor materials & Non-durable & 28,60 & 96,82 & 23,58 & 15,95 \\
\hline Access to a health center & Over 30 mn & 27,17 & 83,37 & 50,43 & 39,60 \\
\hline Access to a water source & Over $30 \mathrm{mn}$ & 16,32 & 96,21 & 8,80 & 5,99 \\
\hline Access to primary school & Over $30 \mathrm{mn}$ & 15,63 & 87,62 & 15,42 & 11,52 \\
\hline Often food problems & Yes & 12,35 & 74,40 & 41,02 & 36,09 \\
\hline Combustible used for cooking & Non-modern & 4,86 & 65,98 & 97,41 & 96,65 \\
\hline \multicolumn{6}{|l|}{ Illustrative variables } \\
\hline Area of residence & Rural area & 72,43 & 93,31 & 93,12 & 65,33 \\
\hline Age of household head & 51 - 99 years & 9,91 & 73,51 & 34,81 & 31 \\
\hline Educational level of household head & Non-educated & 34,16 & 87,09 & 54,56 & 41,01 \\
\hline Educational level of household head & Incomp. Prim. Scho & 8,39 & 76,09 & 17,76 & 15,28 \\
\hline Sex of household head & Male & 8,06 & 67,77 & 81,93 & 79,15 \\
\hline Size of household & 5 - 6 people & 5,35 & 70,12 & 30,49 & 28,47 \\
\hline Size of household & $\begin{array}{l}\text { More than equal to } 7 \\
\text { people }\end{array}$ & 8,03 & 73,40 & 25,97 & 23,16 \\
\hline
\end{tabular}

Source: Author’s calculation using QUIBB 2006

\section{II.2.2 Monetary and multidimensional poverty by the characteristics of household head}

To determine the threshold of non-monetary poverty, the CPI are ranked from smallest to largest value. The positive and negative CPI corresponds to wealth and poverty respectively. The non-monetary poverty line is the value of CPI between the wealthiest among poor households and the poorest among rich households. After making the CPI translation of vector 1.05 in view of having positive $\left(C P I_{i}^{*}\right)$ values which are necessary to use the nonmonetary FGT index, Table 5 gives the following values:

Table 5 -Proportion of households classes according the translated CPI (CPI*).

\begin{tabular}{|c|c|c|c|}
\hline \multirow{2}{*}{$\begin{array}{c}\text { The classes of } \\
\text { households }\end{array}$} & \multicolumn{2}{|c|}{$\begin{array}{r}\text { Translated Composite Poverty } \\
\text { Indicator }\left(\mathrm{CPI}^{*}\right)\end{array}$} & $\begin{array}{c}\text { Proportions of classes } \\
\text { of households (\%) }\end{array}$ \\
\cline { 2 - 3 } & Minimum & Maximum & \\
\hline Poor class & 0 & $\mathbf{1 , 2 3 2 2}$ & $65,47 \%$ \\
\hline Rich class & $\mathbf{1 , 2 3 2 7}$ & 2,1714 & $34,53 \%$ \\
\hline Total & 0 & 2,1714 & $100 \%$ \\
\hline
\end{tabular}

Source: Author's calculation based on QUIBB 2006 
Thus, the formula of multidimensional poverty threshold is:

Multidimensional threshold $(\mathrm{Z})=\left[\max _{C P I_{i}^{*}}(\right.$ poor class $)+\min C P I_{i}^{*}($ rich class $\left.)\right] / 2$

The calculation is equal to: $Z=\left(\frac{1,2322+1,2327}{2}\right)=1,2324$

The value of the multidimensional line is estimated at 1,2324

In order to estimate the monetary level of poverty, the well-being indicator considered is the annual real expenditure which is transformed into annual real expenditure per adult equivalent by implementing the Oxford equivalence score because it's the more popular. The Oxford equivalence scale assigns a value of 1 for the first adult, then 0.7 for all further adults and 0.5 or children aged between 0 and 14 . To define the monetary poverty line, we used the World Bank absolute threshold which is equal to \$1 per head and per day therefore \$365 in 2006 since this year has 365 days. With an exchange rate equivalent on average to 524,4 CFA for \$ 1 in 2006 (www.usherbrooke.ca/perspective-monde, 2011), this threshold for 2006 is 191406 CFA.

Table 6 reveals that the incidence of multidimensional poverty using the cluster corresponds to the weight of the poor class $(65,47 \%)$. This poverty rate is similar to that of the FGT approach while on the monetary level, this ratio stands at $51,78 \%$.

At both monetary and non-monetary levels, poverty is higher among households whose head is male, aged between 51 and 99 and less educated. This scourge for both concepts is also more prevalent in households whose size is increasingly higher and in families living in rural areas. Thus, the situation of multidimensional poverty according to the characteristics of household head is similar to that observed at monetary level.

Table 6-Monetary and multidimensional poverty by the characteristics of household head

\begin{tabular}{|l|c|c|c|c|c|}
\hline $\begin{array}{l}\text { Characteristics of } \\
\text { household head }\end{array}$ & $\begin{array}{c}\text { Multidimensional } \\
\text { poverty incidence } \\
\text { (\%) /Cluster (1) }\end{array}$ & $\begin{array}{c}\text { Multidimensional } \\
\text { poverty incidence } \\
\text { (\%) /FGT approach } \\
\text { (2) }\end{array}$ & $\begin{array}{c}\text { Monetary } \\
\text { poverty incidence } \\
\text { (\%) (3) }\end{array}$ & $\begin{array}{c}\text { Gaps } \\
\text { (1)-(3) }\end{array}$ & $\begin{array}{c}\text { Gaps } \\
\text { (2)-(3) }\end{array}$ \\
\hline Sex of household head & & & & & \\
Male & 67,77 & 67,93 & 55,72 & 12,05 & 12,21 \\
Female & 56,71 & 56,21 & 36,85 & 19,86 & 19,36 \\
\hline & & & & & \\
Age of household head & & & & & \\
& 59,25 & 61,32 & 37,01 & 22,24 & 24,31 \\
15-30 years & 62,57 & 62,43 & 52,73 & 9,84 & 9,7 \\
31-50 years & 73,51 & 72,97 & 59,45 & 14,06 & 13,52 \\
\hline 1-99 years & & & & & \\
Educational level of & & & & & \\
household head & & 86,63 & 69,85 & 17,24 & 16,78 \\
\hline
\end{tabular}




\begin{tabular}{|c|c|c|c|c|c|}
\hline Incomplete prim. school & 76,09 & 75,98 & 54,34 & 21,75 & 21,64 \\
\hline Complete prim. school & 59,29 & 60,22 & 47,50 & 11,79 & 12,72 \\
\hline Incomplete sec. School & 41,6 & 41,90 & 34,66 & 6,94 & 7,24 \\
\hline Complete sec. school & 28,33 & 28,75 & 19,58 & 8,75 & 9,17 \\
\hline Professional school & 8,02 & 8,05 & 7,76 & 0,26 & 0,29 \\
\hline \multicolumn{6}{|l|}{ Size of household } \\
\hline 1-2 people & 50,53 & 49,92 & 10,49 & 40,04 & 39,43 \\
\hline 3-4 people & 63,77 & 63,67 & 41,83 & 21,94 & 21,84 \\
\hline 5-6 people & 70,12 & 70,18 & 63,65 & 6,47 & 6,53 \\
\hline $\begin{array}{l}\text { More than equal to } 7 \\
\text { people }\end{array}$ & 73,40 & 73,96 & 81,91 & $-8,51$ & $-7,95$ \\
\hline \multicolumn{6}{|l|}{ Area } \\
\hline Urban & 13 & 13,53 & 19,74 & $-6,74$ & $-6,21$ \\
\hline Rural & 93,31 & 93,00 & 68,79 & 24,52 & 24,21 \\
\hline Overall & 65,47 & 65,48 & 51,78 & & \\
\hline
\end{tabular}

Source: Author’s calculation from QUIBB 2006

Figure 2 consists in verifying generally the correlation between monetary and non-monetary poverty of households. The link between the translated Composite Poverty Indicators (CPI*) and expenditure per capita shows a positive correlation between both indicators. The correlation coefficient is 0.61 and translates therefore a strong positive relationship between monetary poverty and multidimensional poverty. Hence, living in monetary deprivation leads consequently to non-monetary poverty.

Figure 2-The translated composite indicators (CPI*) (translation of 1,05) by expenditure per adult equivalent

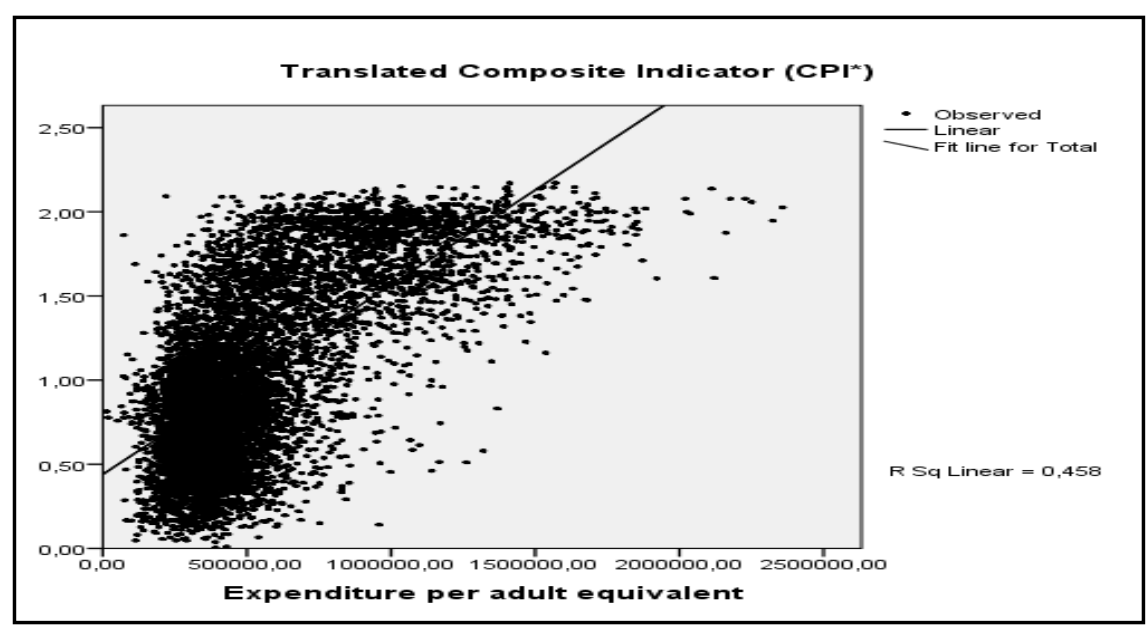

Source: Author’s calculation using QUIBB 2006 


\section{Conclusion and implications of socioeconomic policies}

Because of the multidimensional nature of well-being, it is recognized that the monetary approach is no longer sufficient to account for the multiple phenomena that create poverty within a population. Applied to the case of Togo, the purpose of this paper is the measurement and analysis of non- monetary approach of multidimensional poverty. The data come from the QUIBB 2006 survey which provides non-monetary variables used to construct a CPI.

The results of the incidence of multidimensional poverty according to the cluster analysis techniques and the FGT index reveal that both national poverty rates are similar. The observation of the incidence of poverty among households according to the characteristics of household heads for the two approaches shows that it is higher among households whose head is male, aged between 51 and 99 years, less educated. The multidimensional poverty rate is also higher in households with larger size and for families living in rural areas. The calculation of the incidence of monetary poverty follows the same trend as that of the nonmonetary approach.

In terms of recommendations, we formulate some possible policies for socio-economic development:

\section{- Promote people's access to drinking water sources}

Indeed, actions have been taken by the State, NGOs and local communities to provide rural areas of drinking water sources, but the results have never met the needs to be covered. Ambitious plan is now necessary to expand protected wells and water pumps. The water pumps should be simple and installed by poor household or group of households linked. Communities must be trained for maintenance operations and to intervene in case of damage. This implies a regular contribution in a village bank.

\section{- Promote access to basic infrastructure}

The State must also develop infrastructures such as roads, markets, health centers and schools to bring them closer to rural populations.

The Togolese poor living in rural area have difficulties accessing clinics equipped with qualified personnel $^{3}$, given the remoteness of these health centers. A healthy population is more productive in their various income generating activities. Rural people also have difficulties to sell their crops because the markets are not close. This population needs proper roads to replace the dirt roads in order to facilitate travels.

A higher level of education of future household heads is a guarantee of access to better jobs and therefore income, which reflects positively on the level of non-monetary conditions in housing. The government has for this purpose to build more schools and make them free to provide education to people especially girls. Given that the education system in Togo does not necessarily meet the requirements of improving living conditions and reducing poverty, it is important to redirect educational policy objectives consistent with the realities and therefore contributive to job creation.

\footnotetext{
${ }^{3}$ They often consult traditional healers who do not have the skills to diagnose serious illness
} 


\section{- Promote a policy of housing and sanitation}

Rural houses built with non-resistant materials and often non-electrified are less comfortable than urban habitats. It is well known that the first savings of Togolese are devoted mostly to the purchase of land and construction materials. A policy that would develop the housing sector will inevitably have a positive impact on poverty alleviation. This could also be a solution against unemployment by creating jobs through the activation of related sectors such as masonry, carpentry, scrap merchant, plumbing, electricity, water... The development policy of the housing sector will inevitably have a positive influence on the reduction of poverty. The sanitation problem is a drama in rural and urban Togo with a severity for the rural area. Government actions should consist inter alia in educating, informing households to evacuate household garbage and sewage, developing landfill sites, rehabilitating health services for the improvement of safety and pollution conditions.

\section{- Awareness campaign and targeting age-classes in more worrying situation}

To reduce poverty in the largest male-headed households, it is important to conduct awareness campaigns aimed at changing mentalities. Indeed, one of the causes of monetary poverty resulting in great vulnerability of existence of households headed by men is polygamy, a practice rooted in the custom and resulting in the emergence of large family size.

Poverty is also higher in the households whose heads are in the age range of 51 to 99. Indeed, the majority of these household heads are elderly and retired people. Hence, to tackle the vulnerability of the existence of these people, safety nets must be implemented to help them. However, the other strata should not be neglected in the struggle against the poverty of human existence. Thus, poverty-alleviation policies amongst other microfinance can be focused on the age range of 31 to 50 since they are more active and carry the burden of the entire family. Moreover young unemployment must be addressed seriously by job creation policies.

These measures to reduce non-monetary poverty depend on a genuine desire of policy makers to maximize populations' social well-being.

These few policy proposals made in this study complement those of Body Lawson and al. (2007). Indeed, these authors did not study poverty by the characteristics of the household head. They conducted a breakdown by asset in order to explain their contribution to nonmonetary poverty. If the recommendations on education and habitat are present in the study of Body Lawson and al. (2007), those concerning the sex and age of the household head are not included. In addition, it is difficult to compare this study to others carried out in some African countries. Indeed, the CPI constructed aggregates the non monetary dimensions of well-being revealed in the survey we have used. To find studies from other countries with exactly the same multiple dimensions of well-being is difficult as the content of queries varies according to the context of each country.

The data from QUIBB 2006 do not necessarily reflect the situation of the years that followed. Indeed, the exogenous shocks notably the increase in food prices by 8,4\% in average in 2008 ( IMF Report no. 10/33, 2010) and the floods of 2007 and 2008 likely worsened poverty and inequality. Moreover, according to AfDB, the Organisation for Economic Cooperation and Development (OECD), UNDP and the Economic Commission for Africa ( ECA) (2012 ), the growth rate of real GDP in 2012 is $4.2 \%$ and the inflation rate stood at $2.6 \%$.We do not currently know the combined impact of this inflation control and the growth rate on 
households standard of living. So even though this paper provides an additional contribution to the issue of inequality, the extrapolation of the findings in the following years in order to formulate policies for socio- economic development must be done with great caution.

\section{References}

African Development Fund, African Development Bank (2011) “Togo: Document de stratégie pays 2011-2015” Département des opérations pays-Région d’Afrique de l’Ouest.

AfDB, OECD, UNDP and ECA (2012) “Togo 2012, Perspectives économiques en Afrique 2012”

Alkire, S. (2006) "Choosing Dimensions: the Capability approach and Multidimensional Poverty”, in Kakwani, N., Silber, J., The many Dimensions of Poverty, Washington: Palgrave McMillan

Asselin, L-M. (2002) "Multidimensional Poverty: Composite Indicator of Multidimensional Poverty”, Institut de Mathématique Gauss : Lévis, Quebec

Booysen, F., R. Burger, G. Du Rand, M. Von Maltitz and S. Van Der Berg (2007) "Trends in poverty and inequality in seven African countries”, Cahier de recherché PMMA 2007-06, PEP. February

Bry, X. (1996) “Analyses factorielles multiples”, Economica

Cerioli, A. and S. Zani (1990) “A Fuzzy Approach to the Measurement of poverty”, In C. Dagnum and M. Zenga, editors, Income and Wealth Distribution, Inequality and Poverty, Studies in Contemporary Economics, 272-284, Spinger Verlag, Berlin.

Dagnum, C. and M. Costa (2004) “Analysis and Measurement of Poverty, Univariate and Multivariate Approach and Their Policy Implication. A case of Study: Italy”, In Dagnum C. and Ferrari G. (eds.), Household Behaviour, Equivalence Scales, Welfare and Poverty, Springer Verlag, Germany

Deaton, A. (2003) “Measuring poverty”, Research Program in Development Studies, Princeton University

Directorate General of Statistics and National Accounts (DGSCN) of Togo (2007) "Profil de la pauvreté et de la vulnérabilité au Togo"

Djoke, K. A., and A. E. Agbodji (2009) "Profil de la pauvreté infantile dans quatre pays de l'UEMOA: une analyse comparative basée sur l'approche multidimensionnelle de la pauvreté", Revue africaine de l'intégration 3 (1), 1-61.

Duclos, J.Y. and A. Araar (2006) “Poverty and Negative Incomes”, Technical note.

Escofier, B. and J. Pages (1990) “Analyse factorielles simples et multiples, objectifs, méthodes et interprétation”, Dunod, 284 p. 
Foster, J., J. Greer and E. Thorbecke (1984) “A Class of Decomposable Poverty Measures”, Econometrica 52, 761-766.

IMF (2010) “Togo: Document complet de stratégie de réduction de la pauvreté 2009-2011”, Rapport du FMI, 10/33

Ki, J.B., S. Faye and B. Faye (2005) "Pauvreté multidimensionnelle au Sénégal : une approche non monétaire par les besoins de base”, Cahier de recherche PMMA 2005-05, PEP, Octobre

Lachaud, J.P. (1998) “La pauvreté en Mauritanie : une approche multidimensionnelle”, série de recherche, 31, Université de Montesquieu-Bordeaux IV, Centre d'économie du développement.

Lawson Body, B., K. Baninganti, E. Homevoh, and A.A. Lamadokou (2007) "Analyse comparative de l'état de pauvreté et d'inégalité au Togo: une approche multidimensionnelle basée sur l'indice de richesse” Cahier de recherche PMMA 20072010, Réseau PEP.

Maasoumi, E. (1986) “The measurement and Decomposition of Multidimensional Inequality”, Econometrica 771-779

Meulman, J. J. (1992) “The Integration of Multidimensional Scaling and Multivariate Analysis with Optimal Transformations”, Psychometrika 57 (4), 539-365.

Mussard, S. and M. N. PI Alperin (2005) “Théorie des ensembles flous et décomposition multidimensionnelle de la pauvreté: le cas du Sénégal”, Cahier de recherche 05-03, GREDI, Université de Sherbrooke

Noglo, Y.A. (2014) "Econometric Analysis of Households Living Conditions in Housing in Togo”, Empirical Economics Letters 13 (1), 45-52

Ponty, N. (1998) “Mesurer la pauvreté dans un pays en développement”, Economie et Statistique 90-91, 23-67, INSEE, Paris.

Ravallion, M. (1996) “Comparaisons de la pauvreté : Concepts et méthodes”, Document de travail 122, Banque Mondiale, Washington

Sahn, D.E and D.C. Stifel (2003) "Urban-rural inequality in living standards in Africa”, Journal of African Economies 12, 564-597

Sen, A. (1999) “L’économie est une science morale”, La Découverte, Paris

UNDP (2004) “Action des ONG dans le développement humain durable au Togo”, Rapport national sur le développement humain

UNDP (2011), "Human Development Report”

Volle, M. (1993) “Analyse des données”, Paris

www.usherbrooke.ca/perspective-monde (2011) Perspective monde 


\section{Annexes}

Annex 1.

The eigen values for the first ten axes of the preliminary MCA

\begin{tabular}{|c|c|c|c|c|}
\hline AXES I & $\begin{array}{l}\text { EIGEN } \\
\text { VALUE }\end{array}$ & PERCENTAGE & $\begin{array}{l}\text { CUMULATIVE } \\
\text { PERCENTAGE }\end{array}$ & \\
\hline 1 & 0.3235 & 26.47 & 26.47 & \\
\hline 2 & 0.1101 & 9.01 & 35.48 & 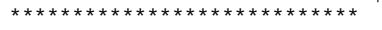 \\
\hline 3 & 0.0735 & 6.01 & 41.49 & $* * * * * * * * * \star * * * * * * * * * *$ \\
\hline 4 & 0.0640 & 5.24 & 46.73 & $\star * \star * \star * * \star * * * \star * * * * *$ \\
\hline 5 & 0.0596 & 4.87 & 51.60 & $* * * * * * * * * * * * * * *$ \\
\hline 6 & 0.0562 & 4.60 & 56.20 & $\star * * * * * * * * * * * * *$ \\
\hline 7 & 0.0532 & 4.36 & 60.56 & $\star * * * * * * * * * * * * *$ \\
\hline 8 & 0.0507 & 4.15 & 64.71 & $\star \star \star \star \star \star \star \star * \star * \star * \star * *$ \\
\hline 9 & 0.0490 & 4.01 & 68.72 & $* * * * * * * * * * * * *$ \\
\hline 10 & 0.0447 & 3.66 & 72.38 & $* * * * * * * * * * * *$ \\
\hline
\end{tabular}

Source: Author’s calculation using QUIBB 2006

The eigen values for the first ten axes of the final MCA

\begin{tabular}{|c|c|c|c|c|}
\hline AXES & $\begin{array}{l}\text { EIGEN } \\
\text { VALUE }\end{array}$ & PERCENTAGE & $\begin{array}{ll}\text { CUMULATIVE } \\
\text { PERCENTAGE }\end{array}$ & \\
\hline 1 & $\begin{array}{r}0.3166 \\
* * * * * *\end{array}$ & $\begin{array}{l}31.66 \\
* \star * * * * *\end{array}$ & 31.66 & \\
\hline 2 & 0.1213 & 12.13 & 43.79 & $* * * * * * * * * * * * * * * * * * * * * * * * * * * * * * * *$ \\
\hline 3 & 0.0754 & 7.54 & 51.33 & $* * * * * * * * * * * * * * * * * * * *$ \\
\hline 4 & 0.0690 & 6.90 & 58.23 & $* * * * * * * * * * * * * * * * * *$ \\
\hline 5 & 0.0612 & 6.12 & 64.35 & $* * * * * * * * * * * * * * * *$ \\
\hline 6 & 0.0598 & 5.98 & 70.33 & $\star * * * * * * * * * * * * * * *$ \\
\hline 7 & 0.0505 & 5.05 & 75.38 & $\star * * * * * * * * * * * *$ \\
\hline 8 & 0.0484 & 4.84 & 80.23 & $\star * * * * * * * * * * * *$ \\
\hline 9 & 0.0419 & 4.19 & 84.41 & $\star * * * * * * * * * *$ \\
\hline 10 & 0.0387 & 3.87 & 88.28 & $\star * * * * * * * * *$ \\
\hline
\end{tabular}

Source: Author’s calculation using QUIBB 2006 


\section{DAVIDSON INSTITUTE WORKING PAPER SERIES - Most Recent Papers}

The entire Working Paper Series may be downloaded free of charge at: www.wdi.umich.edu

CURRENT AS OF 9/23/14

\begin{tabular}{|c|c|c|}
\hline Publication & Authors & Date \\
\hline $\begin{array}{l}\text { No. 1083: Measuring and analyzing the non-monetary approach of } \\
\text { multidimensional poverty by the basic needs in Togo }\end{array}$ & Yawo Agbényégan NOGLO & Aug 2014 \\
\hline $\begin{array}{l}\text { No. 1082: Liquidity Constraints, Loss Aversion, and Myopia: Evidence } \\
\text { from Central and Eastern European Countries }\end{array}$ & Ramiz Rahmanov & Aug 2014 \\
\hline $\begin{array}{l}\text { No. 1081: The Real Exchange Rate and Growth in Zimbabwe: Does the } \\
\text { Currency Regime Matter? }\end{array}$ & $\begin{array}{l}\text { Zuzana Brixiová and Mthuli } \\
\text { Ncube }\end{array}$ & Aug 2014 \\
\hline $\begin{array}{l}\text { No. 1080: Recent Estimates of Exchange Rate Pass-Through to } \\
\text { Import Prices in the Euro Area }\end{array}$ & $\begin{array}{l}\text { Nidhaleddine Ben Cheikh and } \\
\text { Christophe Rault }\end{array}$ & Aug 2014 \\
\hline No. 1079: How smooth is the stock market integration of CEE-3? & $\begin{array}{l}\text { Eduard Baumöhl and } \\
\text { Štefan Lyócsa }\end{array}$ & June 2014 \\
\hline $\begin{array}{l}\text { No. 1078: The Role of the Business Cycle in Exchange } \\
\text { Rate Pass-Through: The Case of Finland }\end{array}$ & $\begin{array}{l}\text { Nidhaleddine Ben Cheikh and } \\
\text { Christophe Rault }\end{array}$ & June 2014 \\
\hline $\begin{array}{l}\text { No. 1077: Skills and youth entrepreneurship in Africa: Analysis with } \\
\text { evidence from Swaziland }\end{array}$ & $\begin{array}{l}\text { Zuzana Brixiova, Mthuli Ncube \& } \\
\text { Zorobabel Bicaba }\end{array}$ & May 2014 \\
\hline $\begin{array}{l}\text { No. 1076: Can Dreams Come True? Eliminating Extreme Poverty In } \\
\text { Africa By } 2030\end{array}$ & $\begin{array}{l}\text { Mthuli Ncube, Zuzana Brixiova } \\
\text { \& Zorobabel Bicaba }\end{array}$ & April 2014 \\
\hline $\begin{array}{l}\text { No. 1074: Bridging the Gender Gap in Entrepreneurship: Evidence from } \\
\text { Europe }\end{array}$ & Elvin Afandi \& Majid Kermani & Feb 2014 \\
\hline $\begin{array}{l}\text { No. 1073: Can Intra-Regional Trade Act as a Global Shock Absorber } \\
\text { in Africa? }\end{array}$ & $\begin{array}{l}\text { Mthuli Ncube, Zuzana Brixiova } \\
\text { \& Qingwei Meng }\end{array}$ & Feb 2014 \\
\hline No. 1072: The Dynamics of Firm Lobbying & $\begin{array}{l}\text { William R. Kerr, William F. } \\
\text { Lincoln and Prachi Mishra }\end{array}$ & Jan 2014 \\
\hline $\begin{array}{l}\text { No. 1071: Skilled Immigration and the Employment Structures of U.S. } \\
\text { Firms }\end{array}$ & $\begin{array}{l}\text { Sari Pekkala Kerr, William R. } \\
\text { Kerr and William F. Lincoln }\end{array}$ & Jan 2014 \\
\hline $\begin{array}{l}\text { No. 1070: Exchange Rate Pass-Through to Domestic Prices } \\
\text { under Different Exchange Rate Regimes }\end{array}$ & Rajmund Mirdala & Jan 2014 \\
\hline $\begin{array}{l}\text { No. 1069: Ailing Mothers, Healthy Daughters? Contagion } \\
\text { in the Central European Banking Sector }\end{array}$ & Tomas Fiala \& Tomas Havranek & Jan 2014 \\
\hline $\begin{array}{l}\text { No. 1068: The Real Exchange Rate and External Competitiveness in Egypt, } \\
\text { Morocco and Tunisia }\end{array}$ & $\begin{array}{l}\text { Zuzana Brixiova, Balázs Égert, } \\
\text { and Thouraya Hadj Amor Essid }\end{array}$ & Jan 2014 \\
\hline $\begin{array}{l}\text { No. 1067: Economic (In)Security And Gender Differences In Trade Policy } \\
\text { Attitudes }\end{array}$ & $\begin{array}{l}\text { Jeffrey Drope and } \\
\text { Abdur Chowdhury }\end{array}$ & Jan 2014 \\
\hline $\begin{array}{l}\text { No. 1066: Do business groups help or hinder technological progress in } \\
\text { emerging markets? Evidence from India }\end{array}$ & $\begin{array}{l}\text { Sumon K. Bhaumik and } \\
\text { Ying Zhou }\end{array}$ & Jan 2014 \\
\hline $\begin{array}{l}\text { No. 1065: Fiscal Imbalances and Current Account Adjustments } \\
\text { in the European Transition Economies }\end{array}$ & Rajmund Mirdala & Nov 2013 \\
\hline $\begin{array}{l}\text { No. 1064: Real Output and Prices Adjustments Under Different Exchange } \\
\text { Rate Regimes }\end{array}$ & Rajmund Mirdala & Nov 2013 \\
\hline
\end{tabular}

